\title{
Individual and overlapping roles of BH3-only proteins Bim and Bad in apoptosis of lymphocytes and platelets and in suppression of thymic lymphoma development
}

\author{
PN Kelly ${ }^{1,2}$, MJ White ${ }^{1,2}$, MW Goschnick ${ }^{1,3}$, KA Fairfax ${ }^{1,2,4}$, DM Tarlinton $^{1,2}$, SA Kinkel $^{1,2}$, P Bouillet ${ }^{1,2}$, JM Adams ${ }^{1,2}$, BT Kile ${ }^{1,2}$ \\ and $A$ Strasser ${ }^{*, 1,2}$
}

BH3-only proteins, such as Bim and Bad, contribute to tissue homeostasis by initiating apoptosis in a cell type- and stimulusspecific manner. Loss of Bim provokes lymphocyte accumulation in vivo and renders lymphocytes more resistant to diverse apoptotic stimuli and Bad has been implicated in the apoptosis of haematopoietic cells upon cytokine deprivation. To investigate whether their biological roles in apoptosis overlap, we generated mice lacking both Bim and Bad and compared their haematopoietic phenotype with that of the single-knockout and wild-type (wt) animals. Unexpectedly, bad $^{-1-}$ mice had excess platelets due to prolonged platelet life-span. The $\mathrm{bim}^{-I-} \mathrm{bad}^{-1-}$ mice were anatomically normal and fertile. Their haematopoietic phenotype resembled that of $\mathrm{bim}^{-/-}$mice but lymphocytes were slightly more elevated in their lymph nodes. Although resting $\mathrm{B}$ and T lymphocytes from $\mathrm{bim}^{-1-} \mathrm{bad}^{-1-}$ and bim $^{-l-}$ animals displayed similar resistance to diverse apoptotic stimuli, mitogen activated bim $^{-I-}$ bad $^{-1-}$ B cells were more refractory to cytokine deprivation. Moreover, combined loss of Bim and Bad-enhanced survival of thymocytes after DNA damage and accelerated development of $\gamma$-irradiation-induced thymic lymphoma. Unexpectedly, their cooperation in the thymus depended upon thymocyte-stromal interaction. Collectively, these results show that Bim and Bad can cooperate in the apoptosis of thymocytes and activated B lymphocytes and in the suppression of thymic lymphoma development. Cell Death and Differentiation (2010) 17, 1655-1664; doi:10.1038/cdd.2010.43; published online 30 April 2010

Programmed cell death (apoptosis), a genetically controlled process for eliminating unwanted cells, is essential for the normal development and function of multi-cellular organisms. ${ }^{1}$ The $\mathrm{Bcl}-2$ protein family has a major role in the regulation of apoptosis in vertebrates. ${ }^{2}$ Its BH3-only members, which include Bad, Bim/Bod, Bik/Blk/Nbk, Hrk/DP5, Puma/Bbc3, Noxa, Bmf and Bid, are essential initiators of apoptosis that are activated in response to distinct developmental cues and cytotoxic signals. ${ }^{3,4}$ They selectively bind to pro-survival members of the $\mathrm{Bcl}-2$ family $\left(\mathrm{Bcl}-2, \mathrm{Bcl}-\mathrm{x}_{\mathrm{L}}, \mathrm{Mcl}-1\right.$, $\mathrm{Bcl}-\mathrm{w}$ and $\mathrm{A} 1)$ and trigger mitochondrial release of cytochrome $c$ by a mechanism requiring their pro-apoptotic relatives Bax or Bak. ${ }^{5,6}$

The BH3-only protein Bad was the first pro-apoptotic $\mathrm{Bcl}-2$ family member found to be regulated by extracellular survival factors. ${ }^{7}$ In cells stimulated with cytokines, such as IL-3, Bad is phosphorylated by AKT (and certain other kinases) on several serine residues, and this inhibits its pro-apoptotic activity by allowing its sequestration by 14-3-3 scaffold proteins or by directly preventing its interaction with $\mathrm{Bcl}-\mathrm{x}_{\mathrm{L}}$ or $\mathrm{Bcl}-2 .{ }^{7,8}$ Conversely, in the absence of survival signals, $\mathrm{Bad}$ is de-phosphorylated, increasing its pro-apoptotic activity. ${ }^{8,9}$ Perhaps surprisingly, however, $\mathrm{bad}^{-1-}$ mice were found to be largely normal. Only minor defects in apoptosis were observed upon withdrawal of IGF-1, EGF or glucose in embryonic fibroblasts or mammary epithelial cells, ${ }^{10,11}$ and some aged $\mathrm{bad}^{-1-}$ mice developed lymphoma. ${ }^{10}$ As Bad loss did not enhance the survival of cytokine-deprived myeloid progenitor cells, ${ }^{12}$ its physiological role in growth factor withdrawal-induced apoptosis remains uncertain.

In contrast, the BH3-only protein Bim, which is regulated by a range of transcriptional and post-translational mechanisms ${ }^{13}$ have a major role in the death of haematopoietic cells induced by cytokine deprivation and certain other apoptotic stimuli, including deregulated calcium flux and, although to a lesser extent, DNA damage. ${ }^{14-16}$ Within the animal, Bim loss provokes accumulation of haematopoietic cells, particularly lymphocytes impairs deletion of autoreactive thymocytes ${ }^{17}$ and $B$ cells, ${ }^{18}$ and is required for shut-down of $T$ cell immune responses. ${ }^{19-21}$ Furthermore, in certain circumstances, Bim deficiency can provoke autoimmune disease ${ }^{14}$ and contribute to lymphoma development. ${ }^{22}$

Despite its major role in haematopoietic cell homeostasis and cytokine deprivation-induced apoptosis, ${ }^{14}$ the loss of Bim provokes less marked effects than the combined loss of $\mathrm{Bax}$ and $\mathrm{Bak}^{23,24}$ or $\mathrm{Bcl}-2$ overexpression, ${ }^{15,25}$ suggesting

\footnotetext{
${ }^{1}$ The Walter and Eliza Hall Institute of Medical Research, Parkville, VIC 3050, Australia and ${ }^{2}$ Department of Medical Biology, Melbourne University, Melbourne, VIC 3010, Australia ${ }^{*}$ Corresponding author: A Strasser, The Walter and Eliza Hall Institute of Medical Research, 1G Royal Parade, Parkville, 3050, Victoria, Australia.

Tel: + 6139345 2555; Fax: + 6139347 0852; E-mail: strasser@ wehi.edu.au

${ }^{3}$ Current address: Centre for Inflammatory Diseases, Monash University Department of Medicine, Monash Medical Centre, Clayton, VIC 3168, Australia.

${ }^{4}$ Current address: The Babraham Institute, Cambridge, CB22 3AT, UK

Keywords: Bim; Bad; BH3-only protein; apoptosis; Bcl-2 family; tumorigenesis

Abbreviations: DNA, deoxyribonucleic-acid; EGF, epidermal growth factor; ERK, Extracellular signal-regulated kinases; FACS, fluorescence activated cell sorting; FITC, fluorescein isothiocyanate; IGF, insulin-like growth factor; IL, interleukin; PI3K, Phosphoinositide 3-kinase; SD, standard deviation; SEM, standard error of the mean; UV, ultra-violet

Received 22.10.09; revised 17.3.10; accepted 30.3.10; Edited by G Melino; published online 30.4.10
} 
that Bim has overlapping functions with other BH3-only proteins. Indeed, although mice lacking Bik are essentially normal, ${ }^{26}$ loss of both Bik and Bim arrests spermatogenesis, ${ }^{27}$ whereas combined loss of Puma and Bim renders haematopoietic cells more refractory to diverse apoptotic stimuli, including cytokine deprivation, than loss of either alone. ${ }^{16}$

As Bad and Bim have been implicated in the apoptosis signalling driven by cytokine withdrawal and DNA damage, as well as in tumorigenesis, we have investigated their potential overlapping functions in cell death by generating Bim/Bad double knockout mice. By analysis of their phenotype, and of purified lymphoid populations in culture, we show that Bim and Bad cooperate in certain apoptotic responses and in the suppression of $\gamma$-irradiation-induced thymic lymphoma. Unexpectedly, some of their cooperation in vivo appears to involve lymphocyte-stromal cell interactions.

\section{Results}

Lymphoid hyperplasia in Bim-deficient mice is slightly increased by concomitant loss of Bad. All progeny of $\mathrm{bim}^{+/-} \mathrm{bad}^{+/-}$and $\mathrm{bim}^{+/+} \mathrm{bad}^{-1-}$ intercrosses developed in the expected Mendelian ratios, but intercrosses of $\mathrm{bim}^{+/-} \mathrm{bad}^{-1}$ animals yielded less than the expected number of $\mathrm{bim}^{-1-} \mathrm{bad}^{\prime-}$ double-knockout offspring (Supplementary Table S1). Their deficit, however, was similar to that of $\mathrm{bim}^{-/-}$progeny from $\mathrm{bim}^{+/-}$intercrosses ( ${ }^{14}$ and $\mathrm{P}$ Bouillet unpublished observations). Thus, the loss of Bad does not augment the penetrance of embryonic death evoked by Bim deficiency.
Bim/Bad doubly deficient mice were fertile and their body and organ weights (Supplementary Figure S1), appearance and behaviour were normal. As $\mathrm{Bim}^{28}$ and $\mathrm{Bad}^{29}$ are both expressed in lymphoid and myeloid cells, we analysed the haematopoietic compartment of 6 to 12-week-old $\mathrm{bim}^{-1-} \mathrm{bad}^{-1-}$ and control (wt, $\mathrm{bim}^{-1-}$, $\mathrm{bad}^{-1-}$ ) mice to determine whether their combined loss exacerbated the leukocyte accumulation in bim $^{-1-}$ mice. ${ }^{14}$ Consistent with previous studies, ${ }^{10,14} \mathrm{bad}^{-1-}$ mice had normal numbers of lymphoid and myeloid cells, whereas Bim-deficient mice had elevated mature B and T cells (Figure 1). The $\mathrm{bim}^{-1-} \mathrm{bad}^{-1-}$ mice displayed increases in $B$ and $T$ lymphocytes similar to those of $\mathrm{bim}^{-1-}$ mice (Figure 1). However, the lymph node cellularity in mice lacking both Bim and Bad was slightly albeit significantly higher $(P=0.05)$ than in bim $^{-1-}$ mice. There was a trend towards increased numbers of granulocytes in spleens of $\mathrm{bim}^{-1-} \mathrm{bad}^{-1-}$ mice (Figure 1) but this did not reach statistical significance. In addition, we found (significantly) increased numbers of nucleated erythroid cells in spleens of $\mathrm{bim}^{-1-} \mathrm{bad}^{-1-}$ and to a similar extent also in $\mathrm{bim}^{-1-}$ mice (Figure 1). We believe, however, that this is not due to abnormally increased survival of these cells but a consequence of a shift of erythropoiesis from the marrow to the spleen (extra-medullary erythropoiesis) due to the overcrowding of the bone marrow by supernumerary $\mathrm{B}$ lymphoid cells, as also seen in $E \mu-b c l-2$ transgenic mice. ${ }^{30}$

Since loss of Bim elevates serum immunoglobulin (lg) levels, ${ }^{14}$ we measured the levels of IgG and IgM by ELISA in the sera of mice either 6-12 weeks or >20-week-old. Whereas loss of Bim provoked a $\sim 5$-fold increase in total serum IgG and IgM levels over wt mice, naïve bad $^{-1}$ mice
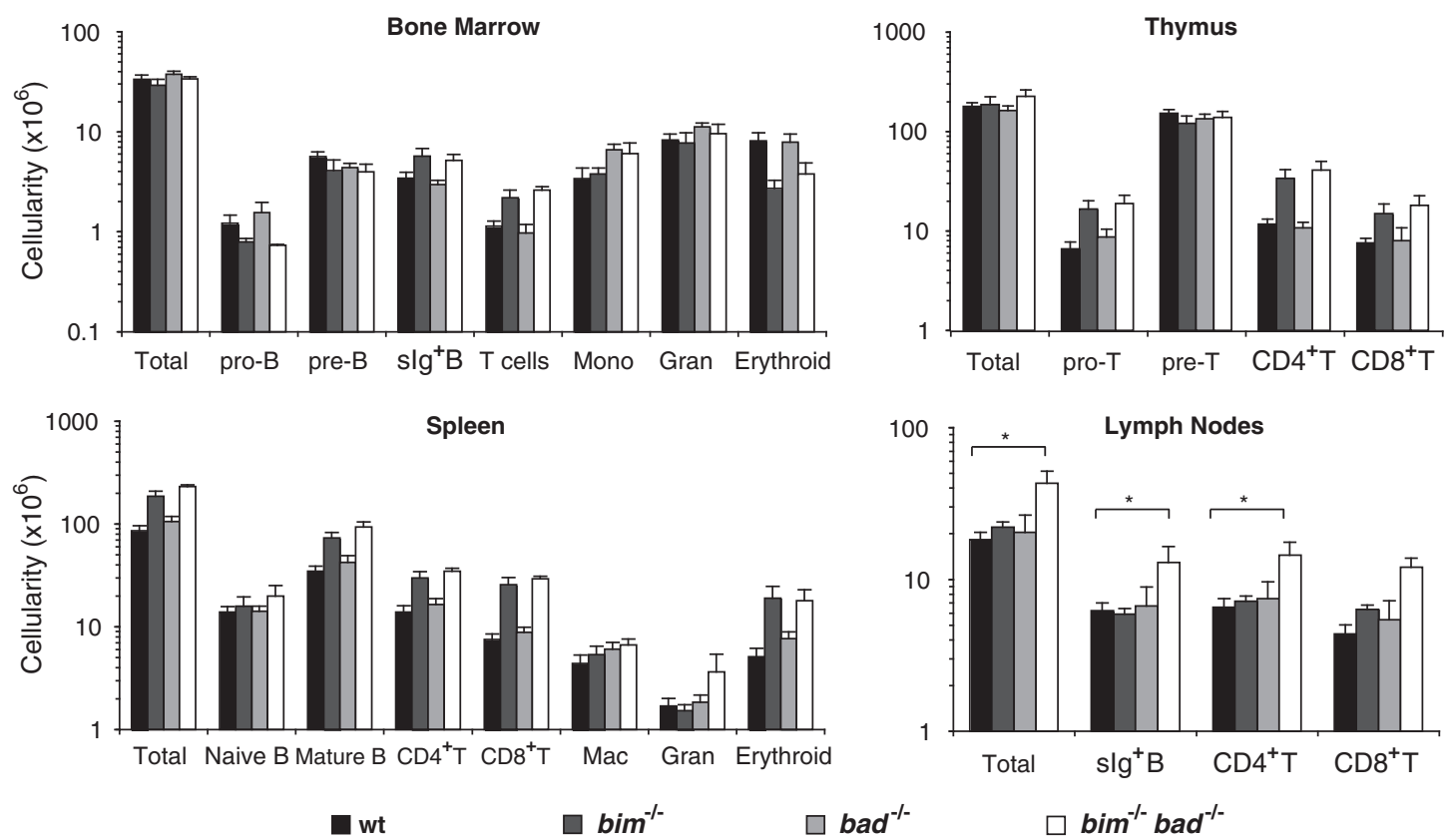

Figure 1 Haematopoietic cell subset composition of $\mathrm{bim}^{-1-} \mathrm{bad}^{-1-}$ and control mice. Cell subset composition analysis of bone marrow, thymus, spleen and lymph nodes (pooled axillary, inguinal and mesenteric) from 6 to 12-week-old bim $^{-1-}$ bad $^{-1-}$ and control bim ${ }^{-1-}$, bad ${ }^{-1-}$ or wt mice. Single cell suspensions were stained with fluorochrome-conjugated surface marker-specific monoclonal antibodies, and the percentages in each cellular compartment quantified by flow cytometric analysis. Total cell numbers were determined by trypan blue exclusion and counting in a haemocytometer. Data represent mean absolute cell numbers \pm S.E. of 4-7 mice of each genotype from at least four independent experiments. An asterisk denotes $P<0.05$ significance in differences between the indicated populations 
showed no increase, and loss of Bim plus Bad did not elevate the levels over loss of Bim alone (Supplementary Figure S2).

Bim-deficient animals (on a mixed C57BL/6x129SV background) develop an autoimmune disorder resembling human systemic lupus erythematosus, ${ }^{14}$ whereas mice lacking Bad were reported to develop diffuse large $B$ cell lymphoma late in life. ${ }^{10}$ Hence, we monitored cohorts of $\mathrm{bim}^{-1-} \mathrm{bad}^{-1-}, \mathrm{bim}^{-1-}$ $\mathrm{bad}^{-1-}$ and wt animals, all on a C57BL/6 background (8-20 generations backcrossed), until 500 days of age for signs of autoimmune disease or haematological malignancy. Only a single $\mathrm{bim}^{-1-} \mathrm{bad}^{-1-}$ mouse succumbed to glomerulonephritis, and none of the 18 other $\mathrm{bim}^{-1-} \mathrm{bad}^{-1-}$ animals or any of the $\mathrm{bad}^{-1}(n=21)$ or $\mathrm{bim}^{-1-}(n=20)$ aged mice examined developed any disease. Hence, the autoimmune disorder that previously manifested in mice lacking Bim appears to depend upon genetic background, even when Bad is also absent, and genetic background may well also have contributed to the low-penetrance lymphoid malignancy reported for aged Baddeficient mice. ${ }^{10}$

Bad deficiency increases platelet numbers and life-span. The Bcl-2 family governs the circulating life-span of platelets. These anuclear cells depend on Bcl- $x_{L}$ for survival, which functions to restrain pro-apoptotic Bak. Mutations in Bak extend platelet life span and cause thrombocytosis. ${ }^{31} \mathrm{We}$ unexpectedly found that Bad-deficient mice had elevated platelet numbers in their peripheral blood (Figure 2a), revealing a previously unidentified role for Bad in platelet homeostasis. Western blotting showed that platelets contain Bad protein (Figure $2 \mathrm{~b}$ ), and since the bone marrow and spleen of $\mathrm{bad}^{-1}$ mice showed normal numbers of megakaryocytes (data not shown), we hypothesized that platelet life-span, rather than production, was perturbed. We therefore examined platelet clearance by labelling platelets with biotin and tracking their survival in vivo. Platelet half-life - defined as the period during which $50 \%$ of labelled platelets had disappeared from circulation - was significantly (albeit modestly) increased in $\mathrm{bad}^{-1-}$ mice (Figure 2c). To examine whether this effect was cell-intrinsic, we performed adoptive transfers of labelled platelets. Upon transfer into wt recipients, the rate of disappearance of $\mathrm{bad}^{-1-}$ platelets was decreased compared with wt platelets (Figure 2d). Thus, Bad regulates platelet life-span in vivo in a cell-intrinsic manner.

The increased platelet numbers in $\mathrm{bad}^{-1}$ mice contrasts with the mild thrombocytopenia previously reported for Bimdeficient animals, ${ }^{14}$ which appears to be due to a reduction in platelet production by megakaryocytes. Remarkably, mice lacking both Bim and Bad had platelet numbers comparable with wt animals (Figure $2 \mathrm{a}$ ), presumably because the reduced platelet production (conferred by Bim-deficiency) was counter-balanced by the enhanced platelet survival (resulting from loss of Bad).

Sensitivity of $\mathrm{bim}^{-I-} \mathrm{bad}^{-1}$ Iymphocytes to apoptotic stimuli in vitro. Bim is critical of the apoptosis of lymphocytes evoked by diverse cytotoxic insults, including

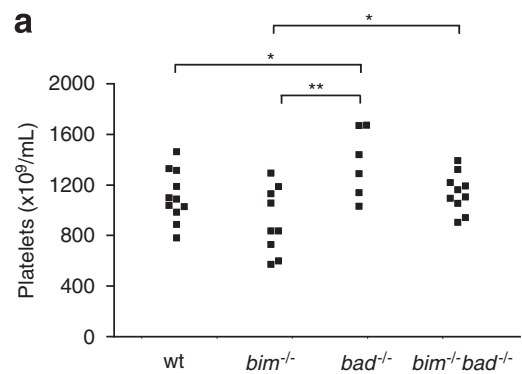

b
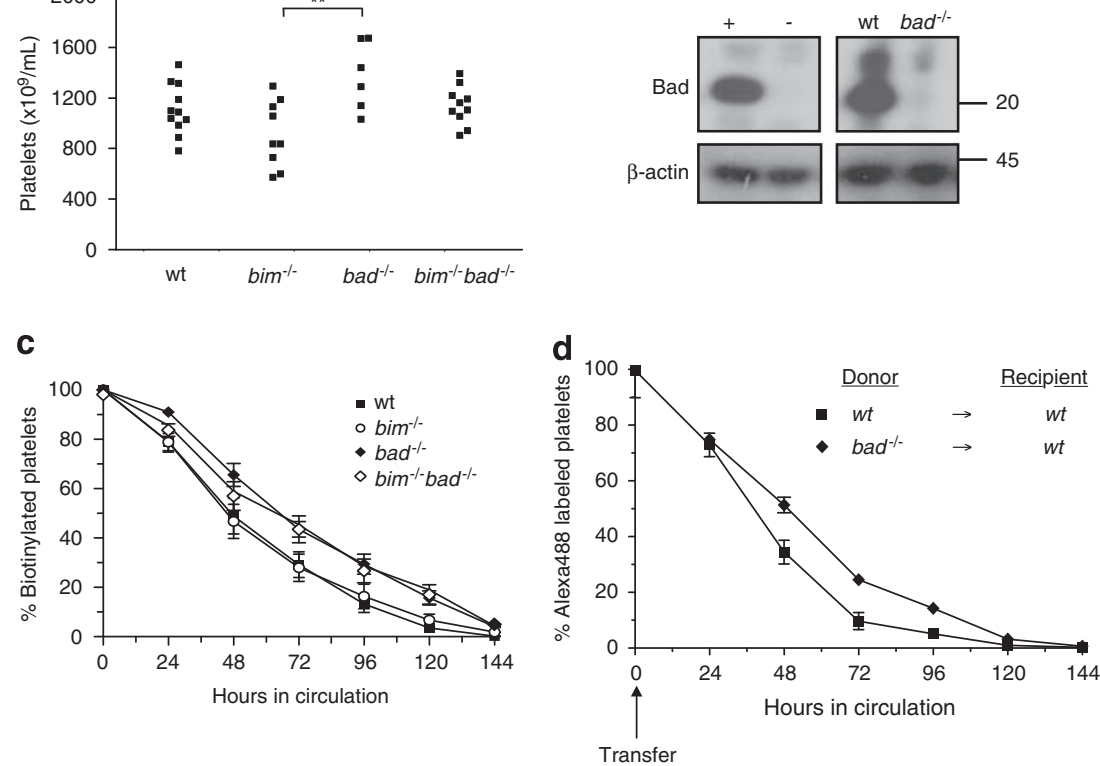

Figure $2 \mathrm{bad}^{-1-}$ but not $\mathrm{bim}^{-1-} \mathrm{bad}^{-1-}$ mice have abnormally increased numbers of platelets. (a) Peripheral blood platelet numbers were determined from 6 - to $12-$ weekold bim ${ }^{-l-} \mathrm{bad}^{-1-}, \mathrm{bim}^{-1-}, \mathrm{bad}^{-1-}$ or wt mice by automated counting (Advia 2120 , Bayer). Data represent absolute numbers $\left(\times 10^{9} / \mathrm{ml}\right)$ of $6-12 \mathrm{mice}$ of each genotype. ${ }^{\star} P<0.05$. (b) Western blot showing expression of Bad in wt platelet lysates and its absence in platelets derived from bad $^{-1}$ mice. The positive control $(+)$ for Bad expression was a lysate of wt mouse embryonic fibroblasts and the negative control $(-)$ a lysate of bad ${ }^{-1}$ mouse embryonic fibroblasts. Results are representative of two independent experiments. (c) Platelet half-life in the circulation was determined in 6 to 12-week-old bim ${ }^{-1-}$ bad $^{-1-}(n=6)$, bim $^{-1-}(n=10)$, bad ${ }^{-1}(n=8)$ or wt $(n=16)$ mice by injection of biotin and flow cytometric analysis of the disappearance of $\mathrm{CD} 41^{+}$biotin ${ }^{+}$platelets (see Materials and methods). Data represent mean \pm S.D. (d) The half-life of transplanted Bad-deficient platelets in the circulation of 8-week-old wt recipient mice $(n=8)$ was determined by adoptive transfer. Alexa488-labelled platelets, derived from $\mathrm{bad}^{-1-}(n=4)$ or wt $(n=4)$ donor mice, were injected into wt recipients and the disappearance of $\mathrm{CD} 41^{+}$Alexa488 ${ }^{+}$platelets monitored by flow cytometry (see Materials and methods). Data represent mean \pm S.D. 
cytokine withdrawal and deregulated calcium flux, ${ }^{14}$ and contributes modestly to DNA damage-induced apoptosis, ${ }^{15}$ even though the bim gene lacks a binding site for the tumour suppressor p53. ${ }^{32}$ To determine whether Bim and Bad have overlapping roles in apoptosis induction, we purified lymphoid sub-populations from $\mathrm{bim}^{-1-} \mathrm{bad}^{-1-}$ and control (wt, bim ${ }^{-1-}$, $\mathrm{bad}^{-1-}$ ) mice and monitored their survival after exposure to a range of apoptotic stimuli in vitro. Bad-deficient lymphocytes were normally sensitive to cytokine deprivation and to DNA damage, evoked either by etoposide or $\gamma$-irradiation (Figure 3). As reported, ${ }^{14,15} \mathrm{bim}^{-1-}$ thymocytes were considerably more resistant than their wt counterparts to cytokine withdrawal and showed minor, albeit significant resistance to $\gamma$-irradiation and etoposide (Figure 3). However, combined loss of Bim and Bad did not enhance thymocyte survival in vitro more than loss of Bim alone (Figure 3 ).

Bim-deficient mature $B$ and $T$ lymphocytes $\left(C D 4^{+} 8^{-}\right.$as well as $C D 4^{-} 8^{+}$) were, as reported, ${ }^{14}$ significantly protected against diverse cytotoxic stimuli, including cytokine deprivation and exposure to dexamethasone, etoposide or $\gamma$-irradiation. However, the concomitant absence of Bad did not provide extra protection (Figure 3, Supplementary Figure S3 and data not shown).

Because the signalling pathways that regulate apoptosis often differ between quiescent and activated cells, we mitogenically stimulated $\mathrm{B}$ and $\mathrm{T}$ cells from $\mathrm{bim}^{-1-} \mathrm{bad}^{\prime-}$ and control mice and monitored their survival in vitro. As reported, ${ }^{14}$ ConA-activated T lymphoblasts from $\mathrm{bim}^{-1-}$ mice were refractory to IL-2 deprivation and modestly protected against $\gamma$-irradiation, but the $\mathrm{bim}^{-1-} \mathrm{bad}^{-1-} \mathrm{T}$ lymphoblasts died at the same rate as their bim ${ }^{-1-}$ counterparts (Figure 3 and data not shown). We also examined splenic B lymphocytes activated in vitro with lipopolysaccharide plus IL-2, IL-4 and IL-5. Following cytokine deprivation, the survival of $\mathrm{bad}^{\prime-}$ and wt B cell blasts was similar, whereas bim ${ }^{-1-}$ B lymphoblasts were highly protected (Figure 3). Interestingly, activated $B$ cells from $\mathrm{bim}^{-1-} \mathrm{bad}^{-1}$ mice were modestly, but significantly $(P<0.05)$, more refractory to cytokine deprivation than bim $^{-1-}$ cells (Figure 3 ). Thus, Bim and Bad have an overlapping role in the control of apoptosis in activated B lymphocytes.

Bim and Bad both contribute to $\gamma$-irradiation-induced thymocyte apoptosis in vivo. DNA damage potently elicits thymocyte apoptosis, mediated largely, ${ }^{33,34}$ albeit not exclusively, ${ }^{35}$ via the tumour suppressor p53. In this response, Puma, a direct p53 transcriptional target, is the rate-limiting $\mathrm{BH} 3-$ only protein, ${ }^{15,36-38}$ but $\mathrm{Bim}$ also contributes $^{14,15}$ and Bad might also have a role. ${ }^{10,39,40}$

To explore the roles of Bim and Bad in the DNA damage response, we subjected wt and p53-deficient mice to $\gamma$-irradiation (5Gy), harvested their thymi $0,4,8$ and $12 \mathrm{~h}$ later, and assessed Bim and Bad expression by Western blotting. Bim levels increased in a p53-independent manner: as early as $4 \mathrm{~h}$ after $\gamma$-irradiation, Bim was detectable at similar levels in both wt and $p 53^{-1-}$ thymocytes (Figure $4 a$ ). By comparison, although the available antibody readily detected Bad in wt fibroblasts (Figure 4a, lane 5), Bad levels were low in untreated wt as well as $p 53^{-1-}$ thymocytes and did not noticeably increase after $\gamma$-irradiation (Figure $4 a$ ).
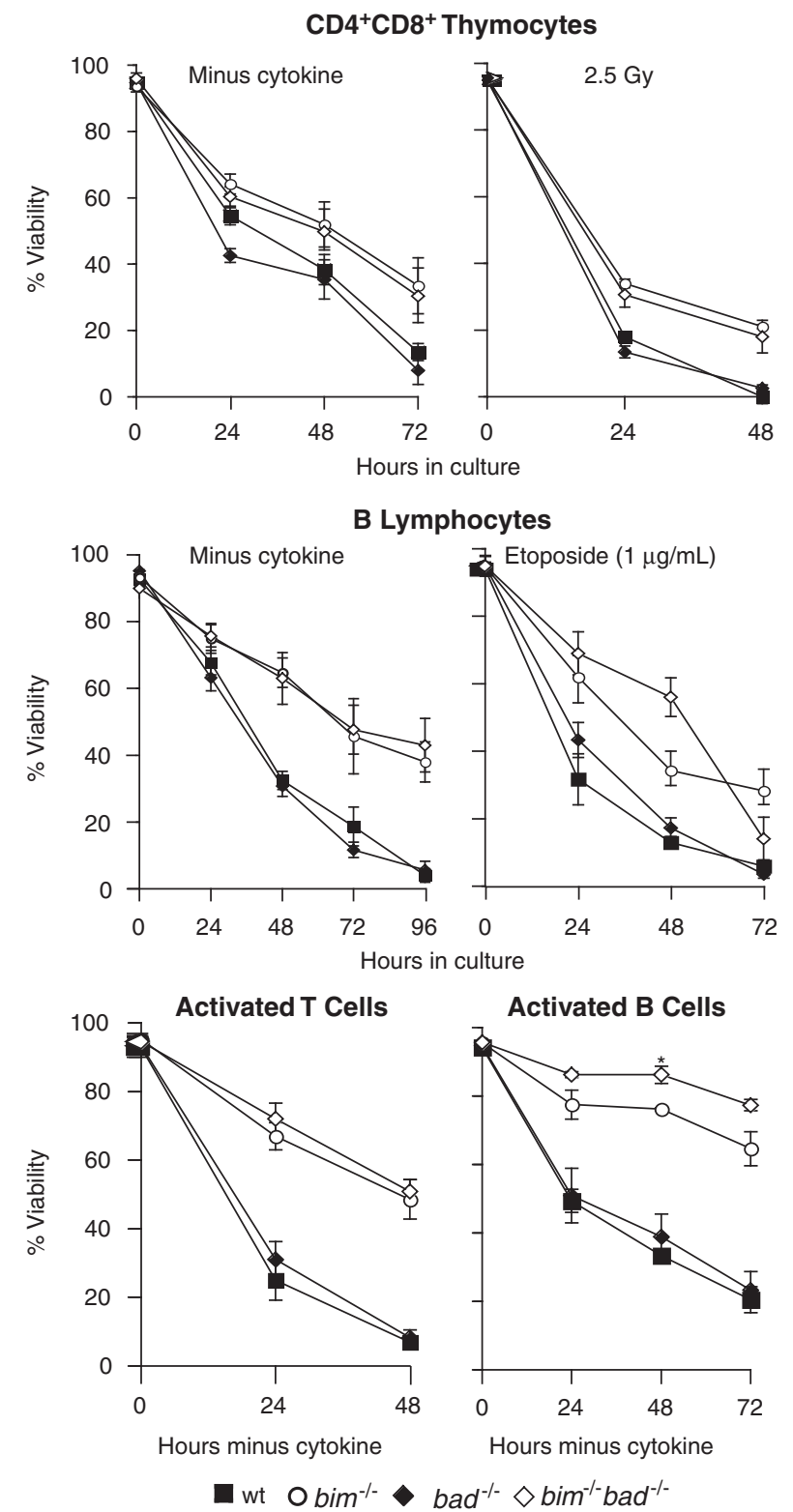

Figure 3 Susceptibility of $\mathrm{bim}^{-1-} \mathrm{bad}^{-1-}$ lymphocytes to apoptotic stimuli in culture. $\mathrm{CD}^{+} 8^{+}$thymocytes and mature $\mathrm{B}$ cells $\left(\mathrm{B} 220^{+} \operatorname{sigM}^{\mathrm{lo}}\right.$ slgD $\left.{ }^{\mathrm{hi}}\right)$ were FACS sorted from thymus or lymph node cell suspensions, respectively, from 6 - to 12-week-old $\mathrm{bim}^{-1-} \mathrm{bad}^{-1-}, \mathrm{bim}^{-1-}, \mathrm{bad}^{-1-}$ or wt mice and cultured with etoposide $(1 \mu \mathrm{g} / \mathrm{ml})$ or subjected to cytokine withdrawal or $\gamma$-irradiation (2.5 Gy). The activated $T$ or $B$ cell blasts were cultured in the absence of cytokines for the indicated times and then stained with FITC-coupled Annexin V plus propidium iodide and the percentages of viable cells quantified by FACS. Data represent mean \pm S.D. of cells from 3 to 5 mice of each genotype

Next, we examined the impact of loss of Bim, Bad or both on the response of lymphoid cells to DNA damage in vivo. Animals were exposed to $5 \mathrm{~Gy} \gamma$-irradiation and their thymus, lymph nodes and spleen harvested $20 \mathrm{~h}$ later. Cell numbers in each haematopoietic organ were determined and the cell subset composition quantified by immunofluorescent staining with surface marker-specific antibodies and FACS analysis. As reported, ${ }^{41}$ wt $C D 4{ }^{+} 8^{+}$thymocytes were highly sensitive 
a
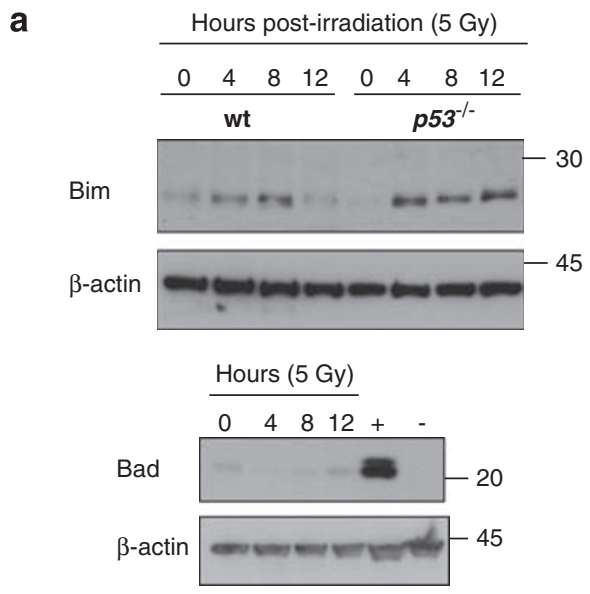

C

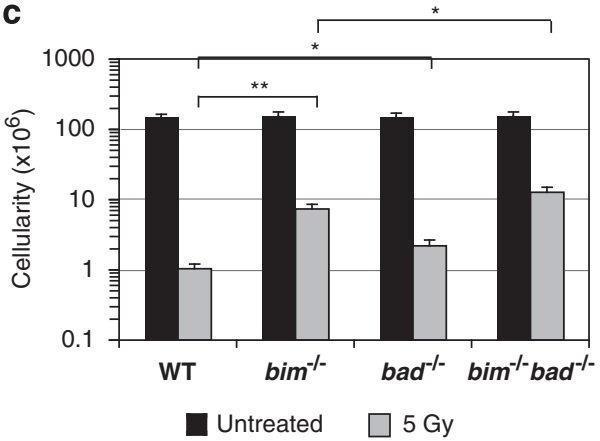

b
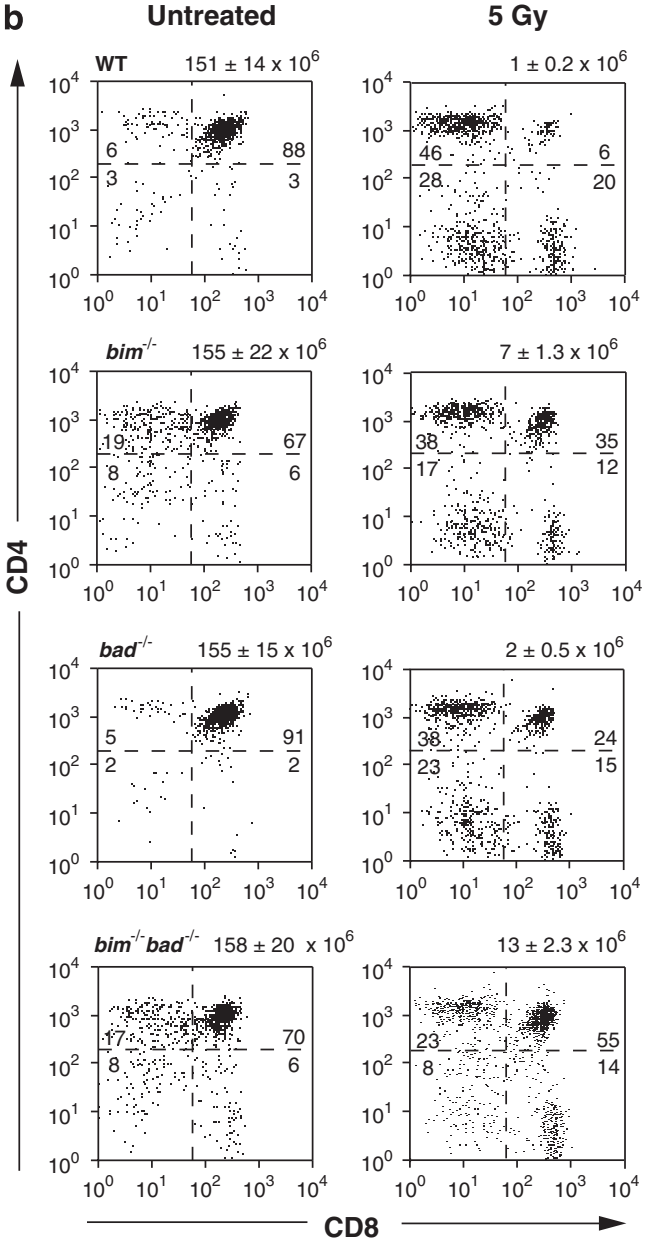

Figure 4 Bim and Bad contribute to $\gamma$-irradiation-induced thymocyte apoptosis in vivo. (a) Western blot showing the effect of $\gamma$-irradiation on Bim and Bad expression in thymocytes, with $\beta$-actin as a loading control. Wt or p53-deficient mice were left untreated or exposed to $\gamma$-irradiation (5 Gy) and lysates made of thymi harvested $0,4,8$ and $12 \mathrm{~h}$ later. The positive control $(+)$ for Bad expression was a lysate of wt mouse embryonic fibroblasts and the negative control $(-)$ a lysate of bad ${ }^{-1-}$ thymocytes. Results are representative of two independent experiments. (b) Effect of $\gamma$-irradiation on thymic cell composition. Wt, bim $^{-1-}$, bad $^{-1-}$ or bim $^{-1-}$ bad $^{-1-}$ mice were exposed to $\gamma$-irradiation ( 5 Gy). Thymi were harvested $20 \mathrm{~h}$ later, and cell viability determined by counting single cell suspensions in a haemocytometer. Cells were stained with monoclonal antibodies to CD4 and CD8 to determine the indicated percentages of the four major thymocyte subsets. The numbers of CD4 ${ }^{+} 8^{+}$thymocytes \pm S.D. before and after $\gamma$-irradiation are shown above the panels. (c) The number of $\mathrm{CD}^{+}{ }^{+} 8^{+}$thymocytes following $\gamma$-irradiation. Data represent the mean \pm S.D. from three independent experiments. $P<0.05\left(^{*}\right)$ and $P<0.01{ }^{(*)}$ are indicated

to $\gamma$-irradiation (Figure $4 \mathrm{~b}$ ), their number plummeting by $\sim 150$-fold (Figure 4c). The Bad-deficient $\mathrm{CD}^{-} 8^{-}$(pro-T) as well as mature $\mathrm{CD} 4^{+} 8^{-}$and $\mathrm{CD}^{-} 8^{+}$thymocytes were killed as efficiently as their wt counterparts. Surprisingly, however, the percentages and total numbers of surviving

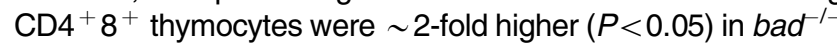
than wt mice (Figure 4b). As reported, ${ }^{15} \mathrm{bim}^{-1-} \mathrm{CD}^{+} 8^{+}$ thymocytes were markedly more resistant than wt cells $(P<0.0001)$ to $\gamma$-irradiation in vivo (Figure $4 \mathrm{~b}$ and $\mathrm{c})$. Notably, the combined loss of Bad plus Bim allowed greater survival $(P<0.05)$ than loss of either $\mathrm{BH} 3$-only protein alone (Figure $4 \mathrm{~b}$ and $\mathrm{c}$ ). Unlike the $\mathrm{CD} 4^{+} 8^{+}$thymocytes, however, the mature $\mathrm{CD}^{+}{ }^{+}$or $\mathrm{CD}^{+} \mathrm{T}$ cells and B cells in $\mathrm{bad}^{-1-} \mathrm{bim}^{-1-}$ mice responded to $\gamma$-irradiation similarly to their $\mathrm{bim}^{-1-}$ counterparts, and loss of Bad alone was not protective (Supplementary Figure S4). These results show that Bim and Bad have overlapping functions in $\gamma$-irradiation-induced killing of $\mathrm{CD}^{+}{ }^{+} 8^{+}$thymocytes within the animal but that Bad does not contribute significantly to the death of their mature $\mathrm{B}$ or $\mathrm{T}$ cells.

Bad contributes to $\gamma$-irradiation-induced apoptosis of $\mathrm{CD}^{+} \mathbf{8}^{+}$thymocytes through a haematopoietic cellextrinsic mechanism. The increased survival of $\mathrm{CD} 4{ }^{+} 8^{+}$ thymocytes in $\gamma$-irradiated $\mathrm{bad}^{-1}$ mice (Figure $4 \mathrm{~b}$ and $\mathrm{c}$ ) was surprising because the expression of Bad in thymocytes was exceedingly low and did not increase after DNA damage (Figure 4a). Thymocyte survival is influenced by its microenvironment, a network of epithelial and haematopoietic cells, including dendritic cells and macrophages. ${ }^{42}$ The observations that $\mathrm{bad}^{-1-} \mathrm{CD} 4^{+} 8^{+}$ thymocytes showed enhanced survival to $\gamma$-irradiation within the animal (Figure $4 b$ and $c$ ) but not as purified cells in culture (Figure 3) suggested that Bad might promote apoptosis of 
$\mathrm{CD}^{+} 8^{+}$thymocytes indirectly through a thymocyteextrinsic mechanism.

To explore this hypothesis, we generated sets of chimaeric animals by reconstituting lethally irradiated wt or bad $^{-1}$ recipient mice with either a wt or $\mathrm{bad}^{-1}$ haematopoietic system. At 8-12 weeks post-reconstitution, the mice were $\gamma$-irradiated (5Gy) and the surviving $\mathrm{CD}^{+}{ }^{+}{ }^{+}$thymocytes enumerated $20 \mathrm{~h}$ later. Both the wt as well as $\mathrm{bad}^{-1}$ thymocytes developing within a Bad-deficient stroma survived $\gamma$-irradiation significantly better $(P<0.05)$ than wt or bad $^{\prime-}$ thymocytes in a wt environment (Figure 5). The $\sim 2$-fold enhanced survival of wt thymocytes in $\mathrm{bad}^{-1-}$ recipients was comparable with that of $\mathrm{bad}^{-1-}$ thymocytes recovered from $\mathrm{bad}^{-1}$ recipients, and to that of thymocytes within unmanipulated (that is, non-chimaeric) $\mathrm{bad}^{\prime-}$ animals (compare Figures 4 and 5). These results show, surprisingly, that Bad must contribute to $\gamma$-irradiation-induced apoptosis of $\mathrm{CD}^{+}{ }^{+} 8^{+}$thymocytes within the animal by acting in nonhaematopoietic cells, most likely thymic epithelial cells (see Discussion). Pertinently, $\gamma$-irradiation provokes both transient and persistent changes to the cellular microenvironment that can facilitate tumorigenesis. ${ }^{43}$

\section{Combined loss of Bim and Bad accelerates $\gamma$-irradiation- induced thymic Iymphoma development. The} reproducible development of thymic lymphoma by C57BL/6 mice subjected to fractionated low doses of $\gamma$-irradiation ${ }^{44}$ provides a robust experimental test for candidate tumour suppressors. Bim ${ }^{22,45,46}$ and to a lesser extent $\mathrm{Bad}^{10}$ have been implicated as tumour suppressors. As both contribute to DNA damage-induced apoptosis of thymocytes, albeit Bim in a haematopoietic cell intrinsic (Figure 4) and Bad in an extrinsic manner (Figure 5), we investigated how their

CD4 ${ }^{+} 8^{+}$Thymocyte Survival After 5 Gy Whole Body Irradiation

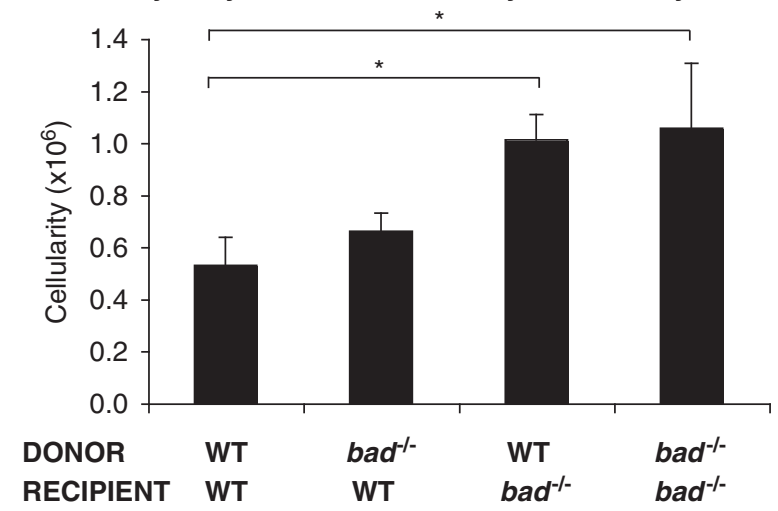

Figure 5 Bad contributes to $\gamma$-irradiation-induced thymocyte apoptosis in a haematopoietic cell-extrinsic manner. Four combinations of bone marrow-derived chimaeric mice were generated by adoptively transferring bone marrow cells from wt or $\mathrm{bad}^{-1-}$ mice into lethally irradiated $\left(2 \times 5.5 \mathrm{~Gy}, 3 \mathrm{~h}\right.$ apart) wt or bad ${ }^{-1}$ recipients. The reconstituted animals were exposed to $5 \mathrm{~Gy}$ whole body $\gamma$-irradiation 8-12 weeks post-reconstitution, and the percentages and total numbers of surviving $\mathrm{CD} 4^{+} 8^{+}$thymocytes determined $20 \mathrm{~h}$ later as described in Figure 4. Data represent mean \pm S.D. from three independent experiments from 4-8 mice of each chimaeric type. Asterisks indicate statistically significant differences, $P<0.05$ individual or combined loss affected $\gamma$-irradiation-induced thymic lymphoma development. We exposed cohorts of wt $(n=10), \quad b^{-1-}(n=16)$, bad $^{-1} \quad(n=22)$, bim $^{-1-} \mathrm{bad}^{-1}$ $(n=10)$ and, as a control, $p 53^{-1-}(n=5)$ mice to fractionated low dose (4 weekly doses of $1.5 \mathrm{~Gy}$ ) $\gamma$-irradiation ${ }^{44}$ and monitored them daily for signs of malignancy.

As reported, ${ }^{47}$ thymic lymphoma developed considerably faster and with higher incidence in $p 53^{-1-}$ mice $(50 \%$ mortality by 14 weeks and $100 \%$ mortality by 18 weeks after the final dose of $\gamma$-irradiation) than in wt animals ( $10 \%$ by 14 weeks and $\sim 50 \%$ by 57 weeks; Kaplan-Meier log rank $P<0.001)$. Although some old $\mathrm{bad}^{-1-}$ mice were reported to develop B lymphoma, ${ }^{10}$ their development of thymic lymphoma ( $\sim 50 \%$ incidence, median latency 60 weeks) was comparable with that of wt mice (Figure 6). Although Bim deficiency (even loss of one allele) markedly accelerates B lymphoma development in $\mathrm{E} \mu$-myc transgenic mice, ${ }^{22}$ bim $^{-1-}$ and wt mice developed $\gamma$-irradiation-induced thymic lymphoma with similar onset and incidence. Remarkably, however, the combined loss of Bim and Bad substantially accelerated $(P<0.04)$ thymic lymphomagenesis $(\sim 80 \%$ incidence, median latency 23 weeks) over that in wt animals $(\sim 50 \%$ incidence, median latency 60 weeks; Figure 6). Histological evaluation of thymic sections from mice of all genotypes revealed a similar extent of tumour dissemination and disruption of the thymic architecture by infiltration of large blast cells (data not shown). Moreover, immuno-phenotyping revealed that most thymic lymphomas, regardless of genotype, were Thy $-1^{+} \mathrm{CD} 4{ }^{+} \mathrm{CD}^{+}$and displayed CD43 and/or CD44 (data not shown). All were transplantable into histocompatible recipients, producing large tumours within 40 days. These results show that Bim and Bad have overlapping roles as tumour suppressors, at least in this model of $\gamma$-irradiation-induced thymic lymphomagenesis.

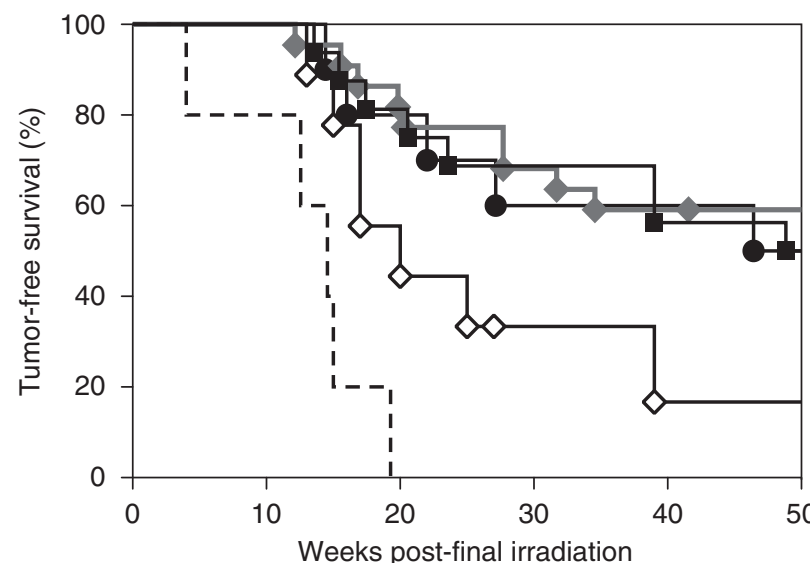

$\checkmark \mathrm{wt} \square \mathrm{bim}^{-/-} \diamond \mathrm{bad}^{-/-} \diamond \mathrm{bim}^{-/-} \mathrm{bad}^{-/-}--\mathrm{p} 53^{-/-}$

Figure 6 Concomitant loss of Bim and Bad accelerates $\gamma$-irradiation-induced thymic lymphoma development. Kaplan-Meier representation of tumour latency in $\mathrm{bim}^{-1-} \mathrm{bad}^{-1-}$ and control $\mathrm{bim}^{-1-}$, $\mathrm{bad}^{-1-}$, wt and $\mathrm{p} 53^{-1-}$ mice following four weekly doses of $1.5 \mathrm{~Gy}$ whole body $\gamma$-irradiation. $\mathrm{bim}^{-1-} \mathrm{bad}^{-1-}$ mice developed $\gamma$-irradiation-induced thymic lymphoma significantly faster $(P<0.04)$ than control mice. Mice were monitored daily for signs of tumour development (hunched posture, laboured breathing and increased spleen/lymph nodes) and sick mice were killed and tissues analysed immediately 


\section{Discussion}

Since both $\mathrm{Bim}^{48,49}$ and $\mathrm{Bad}^{7,8,50}$ can be activated by growth factor deprivation and certain other apoptotic stimuli, we generated Bim/Bad double knockout mice to investigate potential overlaps in their apoptotic function, both within the animal and in cultured lymphoid populations. Perhaps surprisingly, the $\mathrm{bim}^{-1-} \mathrm{bad}^{-1-}$ mice showed only slightly greater lymphadenopathy than the $\mathrm{bim}^{-1-}$ animals (Figure 1), and their resting lymphocytes were no more resistant to cytokine deprivation than the Bim-deficient cells (Figure 3 and Supplementary Figure S3). The absence of synergy between Bim and Bad in these cells is compatible with a model in which neutralisation of all Bcl-2-like pro-survival proteins expressed within a given cell is required to initiate apoptosis efficiently. ${ }^{51-53}$ Because $\mathrm{Bcl}-2$ and $\mathrm{Mcl}-1$ are both highly expressed in resting mature B and T lymphocytes and critical for their survival, ${ }^{54,55}$ complete neutralisation of both these proteins is probably required for their efficient killing. Although Bim and Puma are particularly potent killers because they can engage all the prosurvival proteins, Bad is much less effective because it cannot bind to $\mathrm{Mcl}-1$ (or A1). ${ }^{51,52}$ Thus, in any cell whose survival is sustained by $\mathrm{Mcl}-1$, Bad may only marginally boost Bim's proapoptotic function. In accord with that view, loss of both Puma and Bim elicits more profound and widespread effects on the lymphoid compartment ${ }^{16}$ than combined loss of Bim plus Bad.

Bim and Bad do not cooperate in the development of autoimmunity or spontaneous malignancy. Although quiescent $\mathrm{bim}^{-1-} \mathrm{bad}^{-1-}$ and $\mathrm{bim}^{-1-}$ B lymphocytes showed similar resistance to cytokine deprivation in vitro, mitogenactivated $B$ cells from the doubly-deficient animals were more refractory than Bim-deficient $B$ lymphoblasts (Figure 3 ). This difference may be because $B$ lymphoblasts express higher levels than resting $B$ cells of pro-survival proteins that $B a d$ can neutralise, such as $\mathrm{Bcl}-\mathrm{x}_{\mathrm{L}}{ }^{56}$ The modest increase in resistance of $\mathrm{bim}^{-1-} \mathrm{bad}^{-1-} \mathrm{B}$ cell blasts to cytokine deprivation did not correlate, however, with notable evidence of an abnormally activated immune system. Although many $\mathrm{bim}^{-1-} \mathrm{bad}^{-1-}$ mice presented with larger lymph nodes than $\mathrm{bim}^{-1-}$ mice, their numbers of mature B or T cells and their serum Ig levels were not significantly elevated. Moreover, although a fatal SLE-like autoimmunity was prevalent for $\mathrm{bim}^{-1-}$ mice on a mixed C57BL/6x129SV genetic background, ${ }^{14}$ the $\mathrm{bim}^{-/-}$and $\mathrm{bim}^{-/-} \mathrm{bad}^{-1-}$ mice analysed in this study, all extensively backcrossed to C57BL/6 animals, were not highly susceptible to autoimmune disease, so genetic background clearly has a critical role. Similarly, although it has been reported that aged ( $\sim 18$ month-old) $\mathrm{bad}^{-1}$ mice are prone to develop diffuse large B cell lymphoma, ${ }^{10}$ we observed no malignancies in cohorts of $\mathrm{bad}^{-1-}$ or even $\mathrm{bim}^{-1-} \mathrm{bad}^{-1-}$ animals monitored for a comparable period. Genetic background probably accounts for this difference, because the previous study involved mice on a mixed C57BL/6x129SV background. Pertinently, the 129SV background promotes tumorigenesis in other models of malignancy. ${ }^{57}$

Distinct roles for Bad and Bim in platelet homeostasis. We were intrigued to find that mice lacking
Bad (but not those lacking Bim) have a modest elevation in peripheral blood platelet number (Figure 2a). Our data suggest that the basis for this effect is not an increase in their production, as megakaryocyte numbers were not elevated, but rather an extension of circulating platelet halflife (Figure 2c). Platelet life-span is known to be regulated by the $\mathrm{Bcl}-2$ family of proteins, in particular pro-survival $\mathrm{Bcl}-\mathrm{x}_{\mathrm{L}}$ and pro-apoptotic Bak. ${ }^{31}$ Platelets depend on $\mathrm{Bcl}-\mathrm{x}_{\mathrm{L}}$ to restrain $\mathrm{Bak}$ and maintain viability in the circulation. ${ }^{31,58}$ Loss of function mutations in Bcl- $x_{L}$ cause dose-dependent reductions in platelet life-span ${ }^{31}$ and pharmacological inhibition of $\mathrm{Bcl}-\mathrm{X}_{\mathrm{L}}$ with the $\mathrm{BH} 3-$ mimetic $\mathrm{ABT}-737^{59}$ triggers platelet apoptosis and thrombocytopenia, apparently by freeing Bak and Bax from Bcl- $\mathrm{x}_{\mathrm{L}}$. The mechanism by which this occurs at steady state in vivo is still unclear. One possibility is that $\mathrm{BH}$-only proteins regulate the entry into apoptosis. Intriguingly, a recent study has suggested that Akt-mediated inactivation of Bad facilitates the survival of human platelets in vitro. ${ }^{60}$ Our data show that in the absence of Bad, platelet life span is extended in vivo. Since ABT-737 has the same binding specificity as Bad (Bcl-2, Bcl- $x_{L}$ and $\mathrm{Bcl}-\mathrm{w}),{ }^{61} \mathrm{Bad}$ probably contributes to the initiation of physiological platelet apoptosis by neutralising Bcl- $\mathrm{x}_{\mathrm{L}}$.

Bim and Bad contribute in distinct ways to $\gamma$-irradiationinduced apoptosis of thymocytes in vivo. The major regulator of the cellular response to DNA damage is the p53 tumour suppressor, ${ }^{62}$ which appears to mediate apoptosis primarily by inducing Puma, with minor contributions from Noxa. ${ }^{15,36-38}$ However, p53-independent DNA damageinduced apoptotic pathways exist, as illustrated by the apoptosis following $\gamma$ - or UV-irradiation observed in many tumour cells lacking functional p53. ${ }^{35}$ Indeed, Bim is upregulated by DNA damage in $\gamma$-irradiated p53-deficient thymocytes (Figure 4a), and loss of Bim can protect (albeit only to a minor extent) certain lymphoid cell types from DNA damage-induced apoptosis both in vitro ${ }^{14}$ and in vivo. ${ }^{15}$ How genotoxic insults upregulate Bim is uncertain, but a plausible intermediary is FOXO3A, as it is a critical inducer of bim transcription in cytokine-deprived haematopoietic cells ${ }^{48}$ and can be activated by DNA damage in a p53-independent manner. ${ }^{63}$

Surprisingly, loss of Bad had no effect on $\gamma$-irradiationinduced thymocyte killing in vitro (Figure 3), but it diminished their death in vivo (Figure $4 \mathrm{~b}$ and $\mathrm{c}$ ). Analysis of chimaeric mice (Figure 5) showed that this protective effect was not intrinsic to the $\mathrm{CD} 4{ }^{+} 8^{+}$thymocyte population but rather due to loss of Bad within the thymic microenvironment. These results suggest that following $\gamma$-irradiation a nurturing stromal cell population lacking Bad survives better, presumably rendering it more able to sustain the survival of the thymic T lymphoid cells.

Bim and Bad cooperate in the suppression of $\gamma$-irradiation-induced thymic Iymphoma development. Using the classic low dose $\gamma$-radiation-induced thymic lymphoma model, ${ }^{44}$ we found that combined loss of Bim and Bad, albeit not loss of either BH3-only protein alone, accelerated tumorigenesis, showing functional overlap between these BH3-only proteins in tumour suppression. 
Loss of p53 was more potent in accelerating thymic lymphoma development than combined loss of Bim and Bad; this is consistent with the capacity of p53 to activate multiple tumour suppressive mechanisms in addition to apoptosis, including cell cycle arrest and senescence. ${ }^{62}$

Since Bim and Bad are not thought to be involved in p53-induced apoptosis, how might their combined loss accelerate $\gamma$-irradiation-induced thymic lymphoma development? It is notable that after $\gamma$-irradiation, thymocytes are considerably more numerous in $\mathrm{bim}^{-1-}$ and $\mathrm{bim}^{-l-} \mathrm{bad}^{-1-}$ animals than in wt mice (Figure 4b). Thus, protection conferred by the absence of Bim and/or Bad substantially increases the size of the putative susceptible target population. Furthermore, the elimination of more than $90 \%$ of the more mature cells by the $\gamma$-irradiation (Figure $4 \mathrm{~b}$ ) will provide a strong feedback signal to the immature cells, including nascent neoplastic clones, to proliferate and regenerate the thymus. Indeed, the repeated $\gamma$-irradiation doses both reenforce this impetus and provide the mutagenesis contributing towards malignant progression. ${ }^{44}$ Our observation that Bad deficiency protects the thymic microenvironment from the irradiation (Figure 5) suggests that the stroma lacking Bad can more effectively sustain the emerging neoplastic clones. Accordingly, we propose that the accelerated lymphoma development in $\mathrm{bim}^{-1-} \mathrm{bad}^{-1-}$ animals may reflect a concomitant cell-autonomous enhancement of survival in immature thymocytes, mediated largely by the absence of Bim, and a haematopoietic-extrinsic contribution by a more robust stromal support population, promoted primarily by the absence of Bad. This interpretation of the data would coincide with the view that tumorigenesis often relies on changes in the microenvironment of the emerging malignant clone. ${ }^{43}$ Alternatively, since bone marrow resident haematopoietic stem/progenitor cells that have sustained oncogenic lesions are critical for $\gamma$-radiation-induced thymic lymphoma development, ${ }^{44}$ it is also possible that combined loss of Bim and Bad accelerates tumorigenesis by extending the survival of such 'lymphoma stem cells'.

Evidence is emerging that combined activation of Bim and Bad is not only important for tumour suppression but also has a critical role in anti-cancer therapy. The killing of Bcr-Abltransformed cells by Imatinib (Gleevec) requires Bim and to a lesser extent Bad, ${ }^{64}$ which are both activated by shutdown of PI3K/AKT and ERK signalling. Consequently, our results suggest that treatment of certain types of lymphomas might be improved by agents that target these signalling pathways.

\begin{abstract}
Materials and Methods
Mice. All animal work followed the guidelines of the Melbourne Directorate Animal Ethics Committee. The generation and genotyping of $\mathrm{bim}^{-1-}$ mice, ${ }^{14} \mathrm{bad}^{-1-}$ mice ${ }^{10}$ and $p 53^{-1-}$ mice ${ }^{65}$ has been described previously. These strains of mice were all originally generated on a mixed C57BL/ $6 \times 129$ SV background, using 129SVderived ES cells, but had been backcrossed with C57BL/6 mice for 8-15 generations before use in the studies described here. The $\mathrm{bim}^{-1-} \mathrm{bad}^{-1-}$ mice were generated by intercrossing $\mathrm{bim}^{-1-}$ and $\mathrm{bad}^{-1-}$ mice. Animals were analysed at 6-12 weeks of age unless otherwise specified.
\end{abstract}

Immunofluorescence staining, flow cytometric analysis and cell sorting. Single cell suspensions were prepared from bone marrow, spleen, lymph nodes, peripheral blood or thymus. Cell subset composition was determined by immunofluorescent staining with the following rat or hamster monoclonal antibodies: RA3-6B2 (anti-B220), S7 (anti-CD43), 333.12 or 5.1 (anti-lgM), 11-26C
(anti-lgD), H129 or YTA321 (anti-CD4), YTS169 (anti-CD8), MI/70 (anti-Mac-1), RB6-8C5 (anti-Gr-1), T3.24.1 (anti-Thy-1), IM781 (anti-CD44) and Ter119 (anti-erythroid marker), followed by flow cytometric analysis in a FACScan (BD Biosciences, San Jose, CA, USA). Staining was performed in the presence of

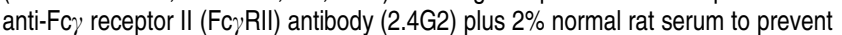
non-specific binding of antibodies. Antibodies were produced in our laboratory and conjugated to biotin (Molecular Probes/Invitrogen, Carlsbad, CA, USA), fluorescein isothiocyanate (FITC, Molecular Probes), cyanine 5 (Cy5, Amersham/ GE Healthcare, Sydney, Australia), R-phycoerythrin (R-PE, Prozyme), or allophycocyanin (APC, Prozyme) according to the manufacturers' instructions. Biotinylated antibodies were visualised by secondary staining using FITC-, PE- or Tricolor-streptavidin conjugates (Caltag/Invitrogen, Carlsbad, CA, USA). Dead cells were excluded by staining with propidium iodide $(2 \mu \mathrm{g} / \mathrm{ml})$. Cell sorting was performed using a MoFlo (Cytomation, Fort Collins, CO, USA) or DiVa (BD Biosciences) high-speed flow cytometer.

Enzyme-linked immunosorbent assay (ELISA). Immunoglobulin levels were measured using ELISA as described. ${ }^{66}$ ELISA plates were coated with goat anti-total mouse immunoglobulin antibodies (Southern Biotechnology Associates, Birmingham, AL, USA) in carbonate buffer. For measurement of total IgG levels, biotinylated goat antibodies specific to mouse IgG1, IgG2a, IgG2b and IgG3 (Southern Biotechnology Associates) were combined for detection, followed by incubation with avidin-HRP and enzymatic detection. For determination of IgM levels, a biotinylated goat anti-lgM antibody was used as the secondary reagent.

Platelet clearance analysis. Mice were injected intravenously (i.v.) with $600 \mu \mathrm{g} \mathrm{N}$-hydroxysuccinimidobiotin (NHS-biotin; Sigma-Aldrich, Sydney, Australia) in buffer containing $140 \mathrm{mM} \mathrm{NaCl}$ and $10 \%$ DMSO. At various time points, whole blood was isolated from the tail vein and mixed with Resuspension Buffer Mix, which comprised $25 \%$ (v/v) Aster Jandl anticoagulant ( $85 \mathrm{mM}$ sodium citrate dihydrate, $69 \mathrm{mM}$ citric acid anhydrans, $10 \mathrm{mM}$ glucose, $\mathrm{pH} 4.6)$ and $75 \%(\mathrm{v} / \mathrm{v})$ resuspension buffer $(10 \mathrm{mM}$ HEPES, $140 \mathrm{mM} \mathrm{NaCl}, 3 \mathrm{mM} \mathrm{KCl}, 0.5 \mathrm{mM} \mathrm{MgCl} 2$ hexahydrate, $0.5 \mathrm{mM} \mathrm{NaHCO}_{3}, 10 \mathrm{mM}$ glucose, $\mathrm{pH}$ 7.4). The buffy coat, containing the platelet fraction, was separated by centrifugation at $125 \mathrm{~g}$ for $5 \mathrm{~min}$ and stained with FITCconjugated rat anti-CD41 monoclonal antibody (BD Biosciences) and PEconjugated streptavidin for $40 \mathrm{~min}$ at room temperature. Samples were washed in wash buffer $(140 \mathrm{mM} \mathrm{NaCl}, 5 \mathrm{mM} \mathrm{KCl}, 12 \mathrm{mM}$ sodium citrate, $10 \mathrm{mM}$ glucose, $12.5 \mathrm{mM}$ sucrose, $\mathrm{pH}$ 6.0) by centrifugation at $860 \mathrm{~g}$ for $5 \mathrm{~min}$. The platelet pellet was resuspended in resuspension buffer before flow cytometric analysis on a FACSCalibur (Becton Dickinson).

Adoptive transfer of platelets. Donor mice (wt or bad ${ }^{-1-} ; \sim 12$ week-old) were injected with $0.1 \mu \mathrm{g} / \mathrm{kg}$ Alexa488-conjugated antibody specific for GPI $\beta$ subunit of GPI $\beta$-V-IX for in vivo platelet labelling (Emfret). Labelling efficiency was assessed by flow cytometry, and only donor mice with $>90 \%$ of the platelet population Alexa488 ${ }^{+}$were used for experiments. Platelets were purified from these donors and injected intravenously into (untreated; $\sim 8$ week-old) C57BL/6 recipients. At various time points, whole blood was isolated from the tail vein of recipients as described (see above under 'Platelet clearance analysis') and the disappearance of Alexa $488^{+}$platelets analysed by flow cytometry.

Immunoblotting. Protein lysates were fractionated using 12\% SDS-PAGE gels (Invitrogen, Carlsbad, CA, USA), and electro-blotted onto nitrocellulose membranes (Hybond C-extra, Amersham/GE Healthcare). Membranes were probed with rabbit polyclonal anti-Bad (Cell Signalling, Danvers, MA, USA) or rat monoclonal anti-Bim (clone 3C5, Alexis/Enzo Life Sciences, Farmingdale, NY, USA) antibodies. Membranes were probed with mouse monoclonal anti- $\beta$-actin (clone AC-74, Sigma) antibodies to show equal loading. Horseradish peroxidase (HRP)-conjugated sheep anti-rabbit immunoglobulin (Ig), goat anti-rat lg (Southern Biotechnology Associates) or sheep anti-mouse Ig antibodies (Chemicon/Millipore, Billerica, MA, USA) were used as secondary reagents and visualised using enhanced chemiluminescence (ECL) reagent (Amersham Biosciences/GE Healthcare). The molecular weight of proteins was measured using the rainbow molecular weight marker cocktail (RPN 756 Amersham Biosciences).

Cell culture and cell death assays. Cells were cultured in the highglucose version of Dulbecco's Modified Eagle's Medium (DMEM) supplemented with $250 \mu \mathrm{M}$ L-asparagine, $50 \mu \mathrm{M}$ 2-mercaptoethanol and $10 \%$ heat-inactivated fetal calf serum (JRH Biosciences, Kansas City, KA, USA). Activated B cells were 
generated by culturing splenocytes for 3 days in medium supplemented with $20 \mu \mathrm{g} / \mathrm{m}$ lipopolysaccharide (Difco) plus IL-2, IL-4 and IL-5 (each at $100 \mathrm{U} / \mathrm{ml})$. Activated B cells were FACS sorted by staining with a cocktail of FITC-conjugated antibodies to CD4, CD8, Gr-1, Mac-1 and Ter119 plus PI and collecting the unstained (FITC $\left.{ }^{-} \mathrm{PI}^{-}\right)$fraction. Sorted activated B cells were typically $>98 \%$ pure as assessed by staining for the B lymphoidspecific marker B220. Activated T cells were generated by culturing spleen cells for 3 days in medium containing Concanavalin A (Con A, $2 \mu \mathrm{g} / \mathrm{ml})$ plus IL-2 $(100 \mathrm{U} / \mathrm{ml})$, followed by 2 days of culture in medium containing IL-2 alone $(100 \mathrm{U} / \mathrm{ml})$. Viable T-cell blasts were FACS sorted by staining with a cocktail of FITC-conjugated antibodies to B220, CD19, Gr-1, Mac-1 and Ter119 plus $\mathrm{Pl}$ and collecting the unstained $\left(\mathrm{FITC}^{-} \mathrm{PI}^{-}\right)$fraction. Sorted T-cell blasts were typically $>98 \%$ pure as assessed by staining with antibodies to CD4 and CD8. Viability of cultured cells was assessed by staining with FITC-coupled Annexin V plus propidium iodide $(2 \mu \mathrm{g} / \mathrm{ml})$ and analysis using a FACScan (Becton Dickinson).

Generation of bone marrow chimaeric mice. Wild-type C57BL/6 Ly5.1, C57BL/6-Ly5.2 or bad $^{-1-}$ (C57BL/6-Ly5.2) mice were subjected to lethal $\gamma$-irradiation $\left(2 \times 5.5 \mathrm{~Gy}-3 \mathrm{~h}\right.$ interval) from a ${ }^{60} \mathrm{Co}$ source at $3.6 \mathrm{~Gy} / \mathrm{min}$. Bone marrow cells $\left(5 \times 10^{6}\right)$ from C57BL/6-Ly5.2 or bad ${ }^{-1-}$ (C57BL/6-Ly5.2) mice were used to reconstitute lethally irradiated C57BL/6-Ly5.1 mice. In addition, we reconstituted lethally irradiated $\mathrm{bad}^{-1-}$ (C57BL/6-Ly5.2) mice with bone marrow from C57BL/6-Ly5.1 or bad ${ }^{-1-}$ (C57BL-6-Ly5.2) mice to serve as controls. Animals were maintained on neomycin supplemented drinking water $(1.6 \mathrm{~g} / \mathrm{l})$ for 14 days post-irradiation to prevent infection, and analysed 8-12 weeks post-reconstitution.

Whole body $\gamma$-irradiation and thymic lymphoma induction experiments. Mice were subjected to 2.5 or $5 \mathrm{~Gy} \gamma$-irradiation. Bone marrow, spleen, thymus and lymph nodes were harvested $20 \mathrm{~h}$ post-irradiation. Single cell suspensions were prepared and total cell numbers determined by trypan blue staining and counting in a haemocytometer. Absolute numbers of cell subsets were calculated by multiplying the percentage of a cell type with the total organ cellularity. For studies on $\gamma$-irradiation-induced thymic lymphoma development, cohorts of wt, $\mathrm{bim}^{-1-}, \mathrm{bad}^{-1-}, \mathrm{bim}^{-1-} \mathrm{bad}^{-1-}$ and $p 53^{-1-}$ mice aged between $25-35$ days were subjected to $1.5 \mathrm{~Gy} \gamma$-irradiation at 7-day intervals over 4 consecutive weeks as described ${ }^{44}$ Mice were monitored daily for signs of malignancy and sick animals killed and subjected to post mortem analysis.

Statistical analysis. Results are expressed as mean \pm S.E. Statistical analysis was performed using the Student's $t$-test. $P$-values less than 0.05 were considered to be statistically significant differences. Kaplan-Meier tumour-free survival curves were constructed using GraphPad Prism software (Version 5), and statistical analysis was performed using the log rank (Mantel-Cox) test.

\section{Conflict of interest}

The authors declare no conflict of interest.

Acknowledgements. We thank Drs S Cory, the late AW Harris, LA O'Reilly and $L$ Lee for gifts of mice, reagents and advice; the late Professor $S$ Korsmeyer and Dr N Danial for bad $^{-1-}$ mice, K Vella, G Siciliano, A Naughton, N lannarella, K Pioch, J Merryfull and M James for expert animal care, B Herbert, C Young, L Tai and M Robati for genotyping, Dr F Battye, V Milovac, C Tarlinton, C Young and $\mathrm{J}$ Garbe for cell sorting, J Corbin for automated blood analysis, Dr S Mihajlovic, E Tsui and A Hasanein for histology, D Quilici, T Nikolaou, G Thomas, S Kwok and D Baum for $\gamma$-irradiation. This work was supported by fellowships and grants from the Cancer Council of Victoria, the Australian National Health and Medical Research Council (Program Grant 257502, Project Grant 516725), the Leukaemia Foundation of Australia, the Sylvia and Charles Viertel Charitable Foundation, the Leukemia and Lymphoma Society (SCOR grant 7015) and the US National Cancer Institute (CA 43540)

1. Strasser A, O'Connor L, Dixit VM. Apoptosis signaling. Ann Rev Biochem 2000; 69 217-245.

2. Adams JM, Cory S. The Bcl-2 apoptotic switch in cancer development and therapy. Oncogene 2007; 26: 1324-1337.

3. Huang DCS, Strasser A. BH3-only proteins - essential initiators of apoptotic cell death. Cell 2000; 103: 839-842.

4. Strasser $\mathrm{A}$. The role of $\mathrm{BH}$-only proteins in the immune system. Nat Rev Immunol 2005; 5 : 189-200.
5. Wei MC, Zong WX, Cheng EH, Lindsten T, Panoutsakopoulou V, Ross AJ et al. Proapoptotic BAX and BAK: a requisite gateway to mitochondrial dysfunction and death. Science 2001; 292: 727-730.

6. Zong WX, Lindsten T, Ross AJ, MacGregor GR, Thompson CB. BH3-only proteins that bind pro-survival $\mathrm{Bcl}-2$ family members fail to induce apoptosis in the absence of Bax and Bak. Genes Dev 2001; 15: 1481-1486.

7. Zha J, Harada H, Yang E, Jockel J, Korsmeyer SJ. Serine phosphorylation of death agonist BAD in response to survival factor results in binding to 14-3-3 not Bcl- $\mathrm{x}_{\mathrm{L}}$. Cell 1996; 87: 619-628.

8. del Peso L, González-Garcia M, Page C, Herrera R, Nuñez G. Interleukin-3induced phosphorylation of BAD through the protein kinase Akt. Science 1997; 278: $687-689$

9. Zha JP, Harada H, Osipov K, Jockel J, Waksman G, Korsmeyer SJ. BH3 domain of BAD is required for heterodimerization with $B C L-X_{L}$ and pro-apoptotic activity. J Biol Chem 1997; 272: 24101-24104.

10. Ranger AM, Zha J, Harada H, Datta SR, Danial NN, Gilmore AP et al. Bad-deficient mice develop diffuse large B cell lymphoma. Proc Natl Acad Sci USA 2003; 100: 9324-9329.

11. Danial NN, Gramm CF, Scorrano L, Zhang CY, Krauss S, Ranger AM et al. BAD and glucokinase reside in a mitochondrial complex that integrates glycolysis and apoptosis. Nature 2003; 424: 952-956.

12. Ekert PG, Jabbour AM, Manoharan A, Heraud JE, Yu J, Pakusch $M$ et al. Cell death provoked by loss of Interleukin-3 signalling is independent of Bad, Bim, and PI3 Kinase, but depends in part on Puma. Blood 2006; 108: 1461-1468.

13. Puthalakath $\mathrm{H}$, Strasser A. Keeping killers on a tight leash: transcriptional and posttranslational control of the pro-apoptotic activity of BH3-only proteins. Cell Death Differ 2002; 9: 505-512.

14. Bouillet $P$, Metcalf $D$, Huang DCS, Tarlinton DM, Kay TWH, Köntgen $F$ et al. Proapoptotic Bcl-2 relative Bim required for certain apoptotic responses, leukocyte homeostasis, and to preclude autoimmunity. Science 1999; 286: 1735-1738.

15. Erlacher M, Michalak EM, Kelly PN, Labi V, Niederegger $\mathrm{H}$, Coultas L et al. BH3-only proteins Puma and Bim are rate-limiting for $\gamma$-radiation and glucocorticoid-induced apoptosis of lymphoid cells in vivo. Blood 2005; 106: 4131-4138.

16. Erlacher M, Laabi V, Manzl C, Bock G, Tzankov A, Haecker G et al. Puma cooperates with $\mathrm{Bim}$, the rate-limiting BH3-only protein in cell death during lymphocyte development, in apoptosis induction. J Exp Med 2006; 203: 2939-2951.

17. Bouillet $\mathrm{P}$, Purton JF, Godfrey $\mathrm{DI}$, Zhang L-C, Coultas L, Puthalakath $\mathrm{H}$ et al. BH3-only Bcl-2 family member Bim is required for apoptosis of autoreactive thymocytes. Nature 2002; 415: 922-926.

18. Enders $A$, Bouillet $P$, Puthalakath $H, X u Y$, Tarlinton DM, Strasser A. Loss of the pro-apoptotic BH3-only Bcl-2 family member Bim inhibits BCR stimulation-induced apoptosis and deletion of autoreative B cells. J Exp Med 2003; 198: 1119-1126.

19. Hildeman DA, Zhu Y, Mitchell TC, Bouillet P, Strasser A, Kappler J et al. Activated T cell death in vivo mediated by pro-apoptotic Bcl-2 family member, Bim. Immunity 2002; 16: 759-767.

20. Pellegrini M, Belz G, Bouillet $P$, Strasser $A$. Shut down of an acute T cell immune response to viral infection is mediated by the pro-apoptotic $\mathrm{Bcl}-2$ homology 3-only protein Bim. Proc Natl Acad Sci USA 2003; 100: 14175-14180.

21. Hughes PD, Belz GT, Fortner K, Budd RC, Strasser A, Bouillet P. Apoptosis regulators Fas and Bim cooperate in shutdown of chronic immune responses and prevention of autoimmunity. Immunity 2008; 28: 197-205.

22. Egle A, Harris AW, Bouillet $P$, Cory S. Bim is a suppressor of Myc-induced mouse B cell leukemia. Proc Natl Acad Sci USA 2004; 101: 6164-6169.

23. Lindsten T, Ross AJ, King A, Zong W, Rathmell JC, Shiels HA et al. The combined functions of proapoptotic Bcl-2 family members Bak and Bax are essential for normal development of multiple tissues. Mol Cell 2000; 6: 1389-1399.

24. Rathmell JC, Lindsten T, Zong W-X, Cinalli RM, Thompson CB. Deficiency in Bak and Bax perturbs thymic selection and lymphoid homeostasis. Nat Immunol 2002; 3 : 932-939.

25. Ogilvy S, Metcalf D, Print CG, Bath ML, Harris AW, Adams JM. Constitutive bcl-2 expression throughout the hematopoietic compartment affects multiple lineages and enhances progenitor cell survival. Proc Natl Acad Sci USA 1999; 96: 14943-14948.

26. Coultas L, Bouillet P, Stanley EG, Brodnicki TC, Adams JM, Strasser A. Proapoptotic BH3only Bcl-2 family member Bik/Blk/Nbk is expressed in hemopoietic and endothelial cells but is redundant for their programmed death. Mol Cell Biol 2004; 24: 1570-1581.

27. Coultas L, Bouillet P, Loveland KL, Meachem S, Perlman H, Adams JM et al. Concomitan loss of proapoptotic $\mathrm{BH} 3-$ only $\mathrm{Bcl}-2$ antagonists Bik and Bim arrests spermatogenesis. Embo J 2005; 24: 3963-3973.

28. O'Reilly LA, Cullen L, Visvader J, Lindeman G, Print C, Bath ML et al. The pro-apoptotic $\mathrm{BH} 3-$ only protein Bim is expressed in hemopoietic, epithelial, neuronal and germ cells. Am J Pathol 2000; 157: 449-461.

29. Mok C-L, Gil G, Williams O, Coles M, Taga S, Tolaini M et al. Bad can act as a key regulator of T cell apoptosis and T cell development. J Exp Med 1999; 189: 575-586.

30. Strasser A, Whittingham S, Vaux DL, Bath ML, Adams JM, Cory S et al. Enforced BCL2 expression in B-lymphoid cells prolongs antibody responses and elicits autoimmune disease. Proc Natl Acad Sci USA 1991; 88: 8661-8665.

31. Mason KD, Carpinelli MR, Fletcher Jl, Collinge JE, Hilton AA, Ellis S et al. Programmed anuclear cell death delimits platelet life span. Cell 2007; 128: 1173-1186. 
32. Bouillet $P$, Zhang LC, Huang DC, Webb GC, Bottema CD, Shore $P$ et al. Gene structure alternative splicing, and chromosomal localization of pro-apoptotic Bcl-2 relative Bim. Mammalian Genome 2001; 12: 163-168.

33. Clarke AR, Purdie CA, Harrison DJ, Morris RG, Bird CC, Hooper ML et al. Thymocyte apoptosis induced by p53-dependent and independent pathways. Nature 1993; 362: 849-852.

34. Lowe SW, Schmitt EM, Smith SW, Osborne BA, Jacks T. p53 is required for radiationinduced apoptosis in mouse thymocytes. Nature 1993; 362: 847-849.

35. Strasser A, Harris AW, Jacks T, Cory S. DNA damage can induce apoptosis in proliferating lymphoid cells via p53-independent mechanisms inhibitable by Bcl-2. Cell 1994; 79 : 329-339.

36. Villunger A, Michalak EM, Coultas L, Müllauer F, Böck G, Ausserlechner MJ et al. p53- and drug-induced apoptotic responses mediated by BH3-only proteins Puma and Noxa. Science 2003; 302: 1036-1038.

37. Jeffers JR, Parganas E, Lee $\mathrm{Y}$, Yang $\mathrm{C}$, Wang J, Brennan $\mathrm{J}$ et al. Puma is an essential mediator of p53-dependent and -independent apoptotic pathways. Cancer Cell 2003; 4: 321-328.

38. Michalak EM, Villunger A, Adams JM, Strasser A. In several cell types the tumour suppressor p53 induces apoptosis largely via Puma but Noxa can contribute. Cell Death Differ 2008; 15: 1019-1029.

39. Datta SR, Ranger AM, Lin MZ, Sturgill JF, Ma YC, Cowan CW et al. Survival factormediated BAD phosphorylation raises the mitochondrial threshold for apoptosis. Dev Cell 2002; 3: 631-643.

40. Jiang P, Du W, Heese K, Wu M. The Bad guy cooperates with good cop p53: Bad is transcriptionally up-regulated by $\mathrm{p} 53$ and forms a Bad/p53 complex at the mitochondria to induce apoptosispoptosis. Mol Cell Biol 2006; 26: 9071-9082.

41. Strasser A, Harris AW, Cory S. BCl-2 transgene inhibits T cell death and perturbs thymic self-censorship. Cell 1991; 67: 889-899.

42. van Ewijk W, Wang B, Holländer G, Kawamoto $H$, Spanopoulou $E$, Itoi $M$ et al. Thymic microenvironments, 3-D versus 2-D? Semin Immunol 1999; 11: 57-64.

43. Barcellos-Hoff MH, Park C, Wright EG. Radiation and the microenvironment tumorigenesis and therapy. Nat Rev Cancer 2005; 5: 867-875.

44. Kaplan HS, Brown MB. A quantitative dose-response study of lymphoid-tumor development in irradiated C57 black mice. J Natl Cancer Institute 1952; 13: 185-208.

45. Tagawa H, Karnan S, Suzuki R, Matsuo K, Zhang X, Ota A et al. Genome-wide arraybased CGH for mantle cell lymphoma: identification of homozygous deletions of the proapoptotic gene BIM. Oncogene 2005; 24: 1348-1358.

46. Sturm I, Stephan C, Gillissen B, Siebert R, Janz M, Radetzki S et al. Loss of the tissuespecific proapoptotic $\mathrm{BH}$-only protein Nbk/Bik is a unifying feature of renal cell carcinoma. Cell Death Differ 2006; 13: 619-627.

47. Kemp CJ, Wheldon T, Balmain A. p53-deficient mice are extremely susceptible to radiation-induced tumorigenesis. Nat Genet 1994; 8: 66-69.

48. Dijkers PF, Medema RH, Lammers JJ, Koenderman L, Coffer PJ. Expression of the pro-apoptotic $\mathrm{Bcl}-2$ family member $\mathrm{Bim}$ is regulated by the forkhead transcription factor FKHR-L1. Curr Biol 2000; 10: 1201-1204.

49. Ley R, Ewings KE, Hadfield K, Cook SJ. Regulatory phosphorylation of Bim: sorting out the ERK from the JNK. Cell Death Differ 2005; 12: 1008-1014.
50. Datta SR, Dudek H, Tao X, Masters S, Fu H, Gotoh Y et al. Akt phosphorylation of BAD couples survival signals to the cell-intrinsic death machinery. Cell 1997; 91: 231-241.

51. Chen L, Willis SN, Wei A, Smith BJ, Fletcher JI, Hinds MG et al. Differential targeting of pro-survival $\mathrm{Bcl}-2$ proteins by their $\mathrm{BH} 3-$ only ligands allows complementary apoptotic function. Mol Cell 2005; 17: 393-403.

52. Kuwana T, Bouchier-Hayes L, Chipuk JE, Bonzon C, Sullivan BA, Green DR et al. BH3 domains of $\mathrm{BH} 3-$ only proteins differentially regulate Bax-mediated mitochondrial membrane permeabilization both directly and indirectly. Mol Cell 2005; 17: 525-535.

53. Willis SN, Chen L, Dewson G, Wei A, Naik E, Fletcher Jl et al. Pro-apoptotic Bak is sequestered by $\mathrm{Mc1}-1$ and $\mathrm{Bcl}-\mathrm{xL}$, but not Bcl-2, until displaced by BH3-only proteins. Genes Dev 2005; 19: 1294-1305.

54. Veis DJ, Sorenson CM, Shutter JR, Korsmeyer SJ. Bcl-2-deficient mice demonstrate fulminant lymphoid apoptosis, polycystic kidneys, and hypopigmented hair. Cell 1993; 75: 229-240.

55. Opferman JT, Letai A, Beard C, Sorcinelli MD, Ong CC, Korsmeyer SJ. Development and maintenance of $B$ and T lymphocytes requires antiapoptotic MCL-1. Nature 2003; 426 : 671-676.

56. Grillot DAM, Merino R, Pena JC, Fanslow WC, Finkelman FD, Thompson CB et al. bcl-x exhibits regulated expression during $B$ cell development and activation and modulates lymphocyte survival in transgenic mice. J Exp Med 1996; 183: 381-391.

57. Donehower LA, Harvey M, Vogel H, McArthur MJ, Montgomery Jr CA, Park SH et al. Effects of genetic background on tumorigenesis in p53-deficient mice. Mol Carcinog 1995 14: 16-22.

58. Zhang H, Nimmer PM, Tahir SK, Chen J, Fryer RM, Hahn KR et al. Bcl-2 family proteins are essential for platelet survival. Cell Death Differ 2007; 14: 943-951.

59. Oltersdorf T, Elmore SW, Shoemaker AR, Armstrong RC, Augeri DJ, Belli BA et al. An inhibitor of Bcl-2 family proteins induces regression of solid tumours. Nature 2005; 435 677-681.

60. Catani MV, Gasperi V, Evangelista D, Finazzi Agro A, Avigliano L, Maccarrone M. Anandamide extends platelets survival through $\mathrm{CB}(1)$-dependent Akt signaling. Cell $\mathrm{Mol}$ Life Sci 2010; 67: 601-610.

61. van Delft MF, Wei AH, Mason KD, Vandenberg CJ, Chen L, Czabotar PE et al. The BH3 mimetic ABT-737 targets selective Bcl-2 proteins and efficiently induces apoptosis via Bak/ Bax if Mcl-1 is neutralized. Cancer Cell 2006; 10: 389-399.

62. Vousden KH, Vande Woude GF. The ins and outs of p53. Nat Cell Biol 2000; 2: E178-E180.

63. Yang JY, Xia W, Hu MC. Ionizing radiation activates expression of $\mathrm{FOXO3a}$, Fas ligand, and Bim, and induces cell apoptosis. Int J Oncol 2006; 29: 643-648.

64. Kuroda J, Puthalakath H, Cragg MS, Kelly PN, Bouillet P, Huang DC et al. Bim and Bad mediate imatinib-induced killing of Bcr/Abl+ leukemic cells, and resistance due to their loss is overcome by a BH3 mimetic. Proc Natl Acad Sci USA 2006; 103: 14907-14912.

65. Jacks T, Remington L, Williams BO, Schmitt EM, Halachmi S, Bronson RT et al. Tumor spectrum analysis in p53-mutant mice. Curr Biol 1994; 4: 1-7.

66. Fischer SF, Bouillet $P$, O'Donnell K, Light A, Tarlinton DM, Strasser A. Pro-apoptotic $\mathrm{BH} 3$-only protein Bim is essential for developmentally programmed death of germinal center-derived memory B cells and antibody forming cells. Blood 2007; 110: 3978-3984.

\section{Supplementary Information accompanies the paper on Cell Death and Differentiation website (http://www.nature.com/cdd)}

